\title{
Investigation of Earthquake Behaviour of Construction System and Materials in Traditional Turkish Architecture
}

\author{
Seyhan Yardiml1 ${ }^{1, *}$, Murat Dal ${ }^{2}$, and Esma Mihlayanlar ${ }^{3}$ \\ ${ }^{1}$ Faculty of Architecture and Design, İstanbul Aydın University, İstanbul, Turkey \\ ${ }^{2}$ Faculty of Engineering, Munzur University, Tunceli, Turkey \\ ${ }^{3}$ Faculty of Architecture, Trakya University, Edirne, Turkey
}

\begin{abstract}
In this study, it is aimed to present a point of view regarding the behaviour of construction systems implemented in traditional Turkish architecture against earthquakes. In the scope of the study, examples of civil architecture were considered and their structures were evaluated as building elements such as foundation, wall and flooring. Traditional Turkish architecture construction systems can be evaluated in two parts. One of them is the wooden carcass system and the other is the unreinforced masonry system. In the wooden carcass system, the carrier is the load bearing elements used in horizontal and vertical directions. Intermediate parts (strut, diagonal etc.) are placed between these elements to form triangles. The triangles (strut, diagonal) used in the wooden skeleton system comprise highly resistant forms against earthquakes. Moreover, due to the internal structure and physical properties of the wood, which is the skeleton material, the flexibility that it maintains can meet the lateral loads of earthquakes. The second construction system which is the system addressed in this application, is the unreinforced masonry system. In this system, the loadbearing system itself is the walls, which are not resistant to lateral loads. In order to provide this flexibility beams (hat1lar) are installed at certain intervals. After the wall is built to a certain height, a different material is laid allowing a plane of movement on the wall. Thus, when the wall is exposed to a lateral load, it escapes from the planes where the beams (hat1llar) are present, and is protected against large damages by absorbing the earthquake load. In order to establish that the foundation of the structure can withstand earthquakes by movement, wood is placed at the lower part of the foundation above a layer of sand ensuring lateral movement and flexibility of the building. In traditional buildings the slabs are connected to the building walls with beams (hatillar). Through the agency of the beams (hatillar) formed at the connection points, the slabs can act as a mass so that they can meet the earthquake load. Allowing the structure to move makes it resistant to earthquakes, seismic isolators are used for this purpose by absorbing the earthquake load and moving the foundation of the structure.
\end{abstract}

\footnotetext{
${ }^{*}$ Corresponding author: seyhanyardimli@gmail.com
} 


\section{Introduction}

One of Turkey's most active earthquake belts is situated along the Alpine Himalayan earthquake fault [1]. From time to time, much destruction occurs in this geography. Structures that are built using traditional methods as well as those with reinforced concrete have been reduced to rubble in these natural disasters, leading to discussions surrounding the importance of both construction systems as well as building quality. In some cases, local people use durable building construction techniques and these techniques have not yet been tested by modern engineers [2].

From the standpoint of carrier characteristics of buildings that incorporate the traditional system in Turkey, these can generally be taken up in two categories, the wooden framed and masonry construction systems. In considering these two systems from the aspect of earthquake resistance, the wooden frame system appears to be more resistant. In touching briefly upon the frame system in this study, we'll be actually dealing with the masonry system, and take up construction elements that protect the structure against lateral loads and boost the system's resistance against earthquakes in today's structures.

\section{Behavior of a Wooden-Frame Structure During Earthquakes}

The frame system is comprised from horizontal and vertical bearings positioned on a prepared foundation. Composed of horizontal and vertical elements, these main carriers form rectangular or square forms. The durability of these forms is boosted by placing cross elements between them. Because a wooden framed system is comprised of a form made from triangles, it is extremely rigid (Table 1.a). While square or rectangular forms are more susceptible to deformation due to the lateral effect, triangular forms are much less susceptible to deformation via lateral load (Table 1.b). While it was observed wooden framed structures weren't damaged, numerous reinforced structures collapsed [3] during the 1999 Marmara-region earthquakes centered in Gölcük and Düzce.

Table 1. The utilization of the triangle form in the wooden frame system

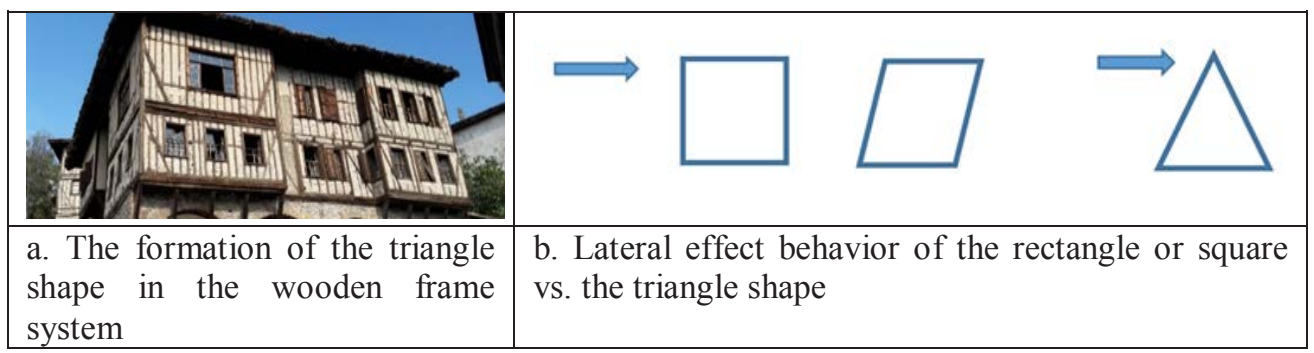

\section{Behavior of a Masonry System Structure in an Earthquake}

The behavior of the foundation, walls and the roof of a building constructed in the masonry system will be taken up in this section. 


\subsection{The Impact of Earthquake on Masonry Building Foundations}

In taking a look at foundations of historical structures in which traditional construction system have been applied, it is observed a system was utilized in these elements that dampen the effect of an earthquake. A layer of $15-20 \mathrm{~cm}$ thick of sand or pebbles was spread, or else a wooden grid that facilitates the possibility of movement in this system was first laid beneath the foundation (Table 2) [4]. Moreover, the foundations of historical structures were protected from the effects of water and ventilated with peripheral wells or galleries [5].

Table 2. The positioning of the foundation in a traditional construction system to counter earthquake loads

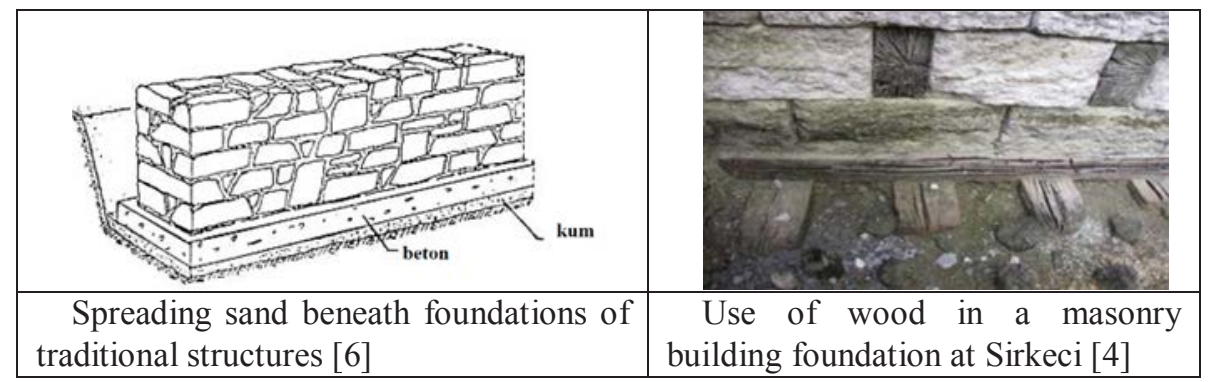

In recent years, interest has intensified on systems that absorb the effect of earthquakes within the structure [7]. The objective is to ensure that the structure behaves rigidly on the vertical side and flexibly on the horizontal side in countering the effect of an earthquake. Fort his, floor insulators were positioned in the foundation [8]. Examples of shock absorbers are seen in the foundation in Table 3.

Table 3. Examples of floor insulators and absorbers which are imbedded in the foundation in contemporary structures [7]

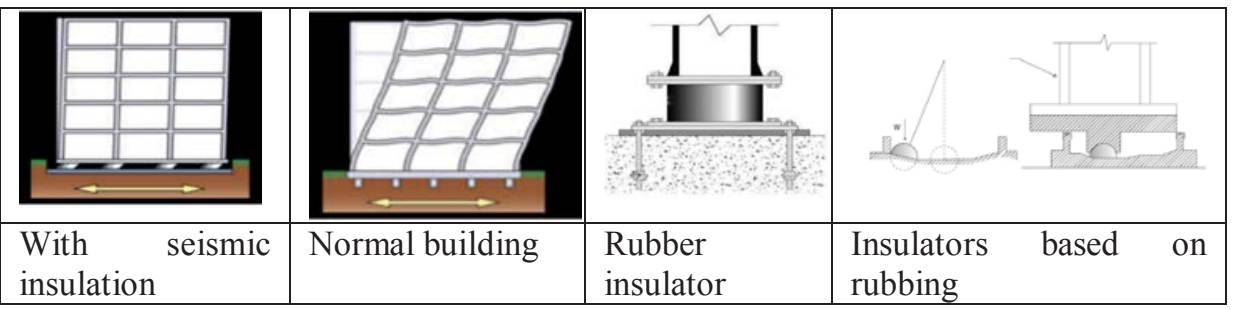

\subsection{Earthquake Effects in Wall Elements}

In comparing masonry structures to reinforced concrete framed structures, the wall in masonry systems are simple and continual, serving as a curtain door [9]. In masonry structure walls, the tensile strength of wall blocks is very low. For this reason, damage occurs in the face in for this reason, damage is seen in the direction of the plane of the wall or against the load that stands perpendicular to the wall. The beam element is utilized in traditional structures in order for earthquake loads to be absorbed within the wall in a masonry system. The Hatil facilitates the hatil arrangement sliding plane that allows the wall to move. This sliding plane ensures that the structure wall remains stable by absorbing the tension the earthquake causes in the horizontal direction. Beams begin to be imbedded in the wall from a height of $80-100 \mathrm{~cm}$ above the floor and are spaced at intervals of $100-$ 
$150 \mathrm{~cm}$. These dampening planes reduce the earthquake load by pulling it from the height of the wall down to the height of the beam. This proves is seen in Table 4.

Table 4. Earthquake behavior in masonry structure walls

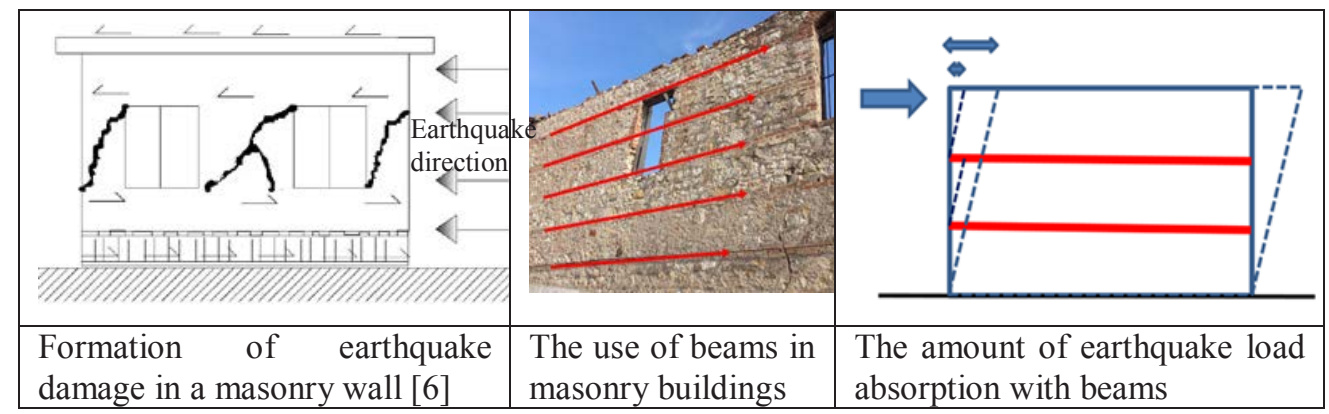

'In some regions of the world, timber or brick bands are used to enhance the wall stability in both uncoursed random rubble and semi-dressed masonry. This is a traditional practice in some parts of Nepal, İndia, Pakistan, Turkey and Greece' [10]. Recommended use of timber and reinforced concrete bands (hatils) in Turkish stone masonry are shown in the figure 1 .
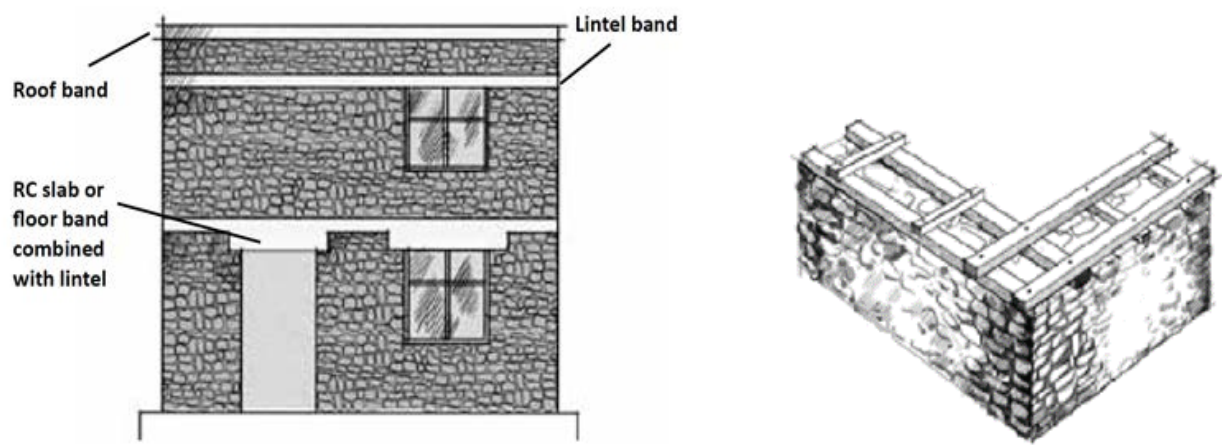

Fig. 1. Reinforced concrete and timber bands [10]

The wooden reinforced stone wall technique known as Bhatar is used for postearthquake housing needs in northern parts of Pakistani (Fig 2) [2].

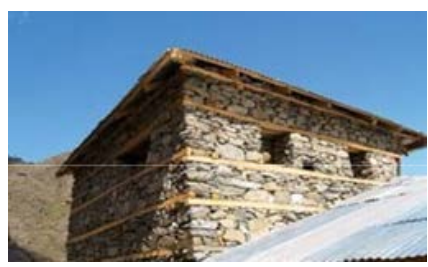

Fig. 2. New house in Tarand, Battagram [2] 
To increase the strength of the buildings, T. Schacher recommends plinth beam, sill band, lintel band and bond beam (Figure 3) [11].

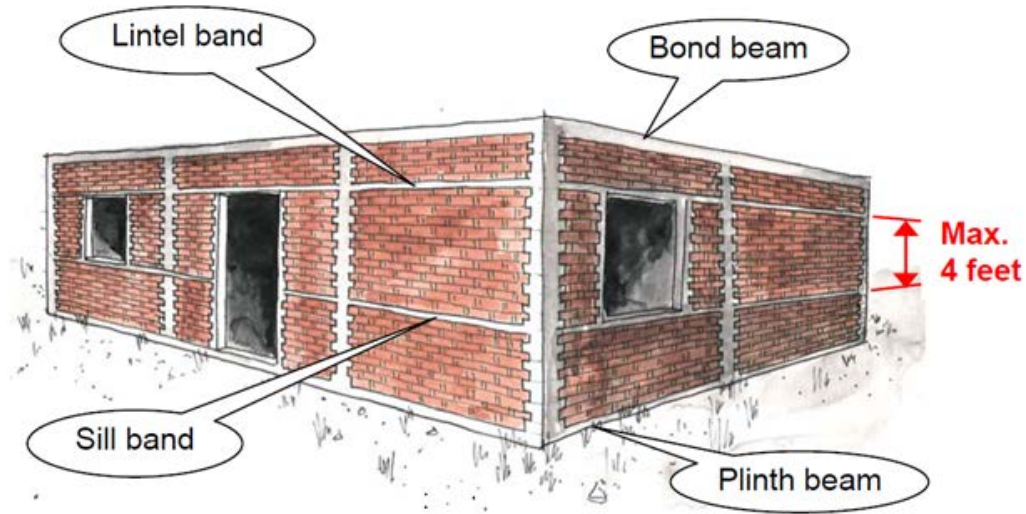

Fig.3. Increasing the stability of a building against earthquake [11]

It is crucial for the walls of masonry structure to be of the required quality and standards. In reality, it is observed that wall formation regulations were complied with inadequately in numerous collapsed structures (Table 5).

Table 5. 2017 Causes of damage in collapsed walls in the Çanakkale Ayvacık earthquake

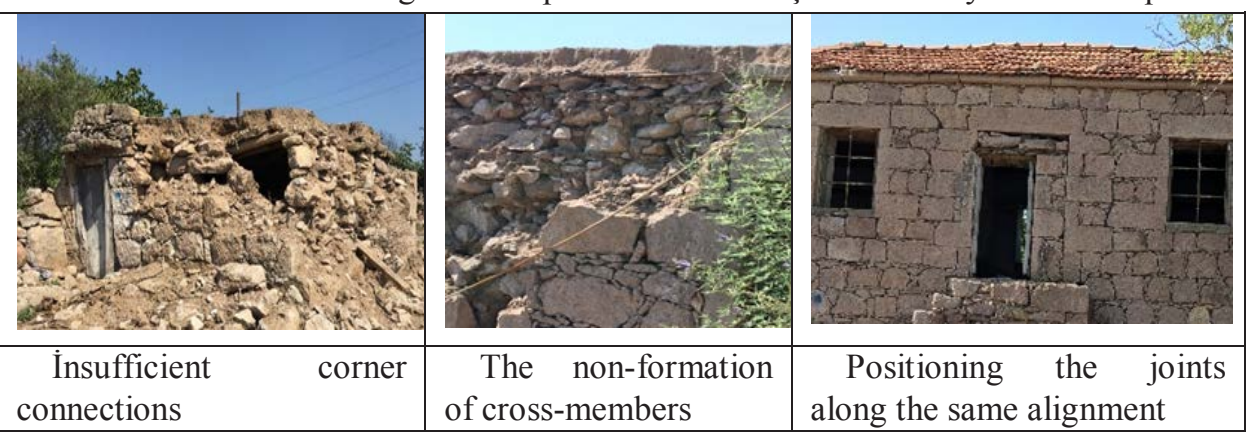

Beams that are installed in traditional masonry structures are made from materials such as wood, concrete and brick (Table 6).

Table 6. Samples of beam material types

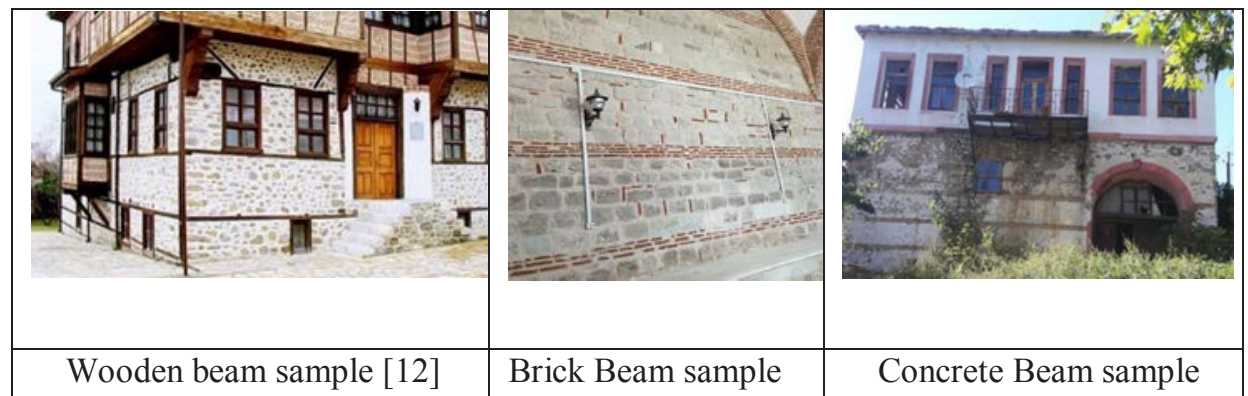




\subsection{Earthquake Impact on the Roof Element as a Building Cover}

Only roof coverings applied in housing were considered within the study of civil architecture examples. As the roof covering for masonry construction systems, the general application is either a flat roof covered with soil, or else a wooden room covered with adobe tiles. The roof must be of the quality to shift the load to the upper portion of the walls and ensure rigidity in itself. Concurrently, the walls must be able to bear the load coming from the roof itself [13]. The roof must be properly positioned over trailing edge elements at the top of the wall. This trailing edge element can either be wooden floor joist or a reinforced concrete beam. During an earthquake, the separation of the joists from the wall, and subsequent roof collapse is due to the little distance of the roof beams positioned over the wall. Excessive loads of soil-covered rooftops also increases the rate of impact with an earthquake load. As a consequence of the collapse of the walls, the roofs on top of them collapse as their ability to bear the load disappears.

In determinations made in the Ayvacik earthquake zone, it was observed excessive damage occurred due to the failure to apply proper construction techniques (Table 7).

Table 7. Roof damage

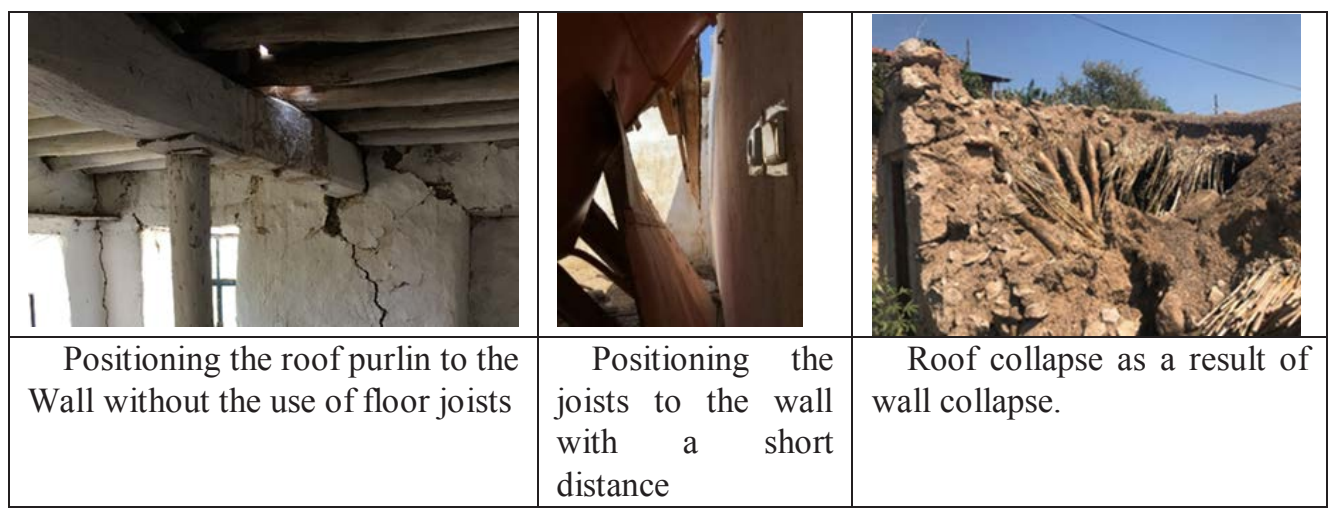

\section{Conclusion}

Earthquakes have occured throughout history in this geography which is in an earthquake belt. In this regard, several examples can be provided. In reviewing one or two of these with the objective of assessing the construction systems; 14,156 buildings were damaged in the 1995 Dinar Earthquake, whereas wooden framed structures sustained little or no damage. The amount of damage sustained in masonry structures in the 1992 Erzincan and 1995 Dinar earthquakes was found to be of a lower rate than other structures [9]. Langenbach stated that masonry structures remained more intact than reinforced concrete buildings as a result of the earthquake that struck Armenia on 7 December, 1988 [14]. Engineers examine mainly reinforced concrete structures in research conducted in earthquake regions, whereas buildings constructed with traditional systems are not paid the necessary attention and care.

In 2005 Pakistani earthquake showed that not only traditional masonry buildings but also reinforced concrete frame structures were collapsed down. On the other hand, 
traditional timber-reinforced buildings resisted well enough [2].

In conducting inspections, it is seen that most buildings damaged in this quake did not comply with required construction techniques and that the structures were erected haphazardly. In reality, the necessary precautions for rendering masonry structures resistant to earthquakes are known. The problem often arises from the failure to implement these measures.

In the traditional construction system, the planning of the building foundation so that it absorbs earthquake shocks is being used by adapting today's conditions as well as in the technology that is available at present. For this reason, it appears that technique applied in traditional masonry structures is correct.

The use of beams in the wall system also creates earthquake load absorption surfaces. Thus, the wall is not affected by the earthquake load as a large mass, but rather as a short distance between two beams. The load on the roof is also reduced as a result of earthquake load dampening by the beams imbedded in the wall.

The preservation of traditional systems is required from the aspect of building culture continuity. In terms of building physics, these buildings are also more advantageous in regards to providing thermal comfort. In terms of production and utilization of materials that go into the production process in their production systems are also more eco-friendly.

Therefore, rather than pretending structures produced with the traditional system don't exist, it is more beneficial to approach this type of home structure, which is still inhabited to a major extent in rural areas, in a constructive and solution-minded manner.

\section{References}

1. http://www.icisleriafad.gov.tr/ulkemizin-deprem-riski-haritas1, Access:19.04.2018

2. T. Schacher, Good Engineering without Appropriate Communication doesn't lead to Seismic Risk Reduction: some thoughts about appropriate knowledge transfer tools, The 14th World Conference on Earthquake Engineering, Beijing, China, (2008)

3. Z. Ahunbay, Geleneksel Yapılar ve R. Langenbach'la Söyleşi, Yapı Mimarlık Kültür ve Sanat Dergisi, Vol: 228, 101, (2000)

4. G. Arun, TMMOB İnşaat Mühendisleri Odası Gaziantep Eğitim Semineri, Slide:19, Slide:10, (2016)

5. A. Bayraktar, 'Tarihi Yığma Yapıların Depreme Karşı Güçlendirilmesi', YDGA 2005-Yı̆̆ma Yapıların Deprem Güvenliğinin Arttırılması Çalıştayı, 4, (2005)

6. G. Arun, Yığma Kagir Yapı Davranışı, YDGA 2005-Yığma Yapıların Deprem Güvenliğinin Arttırılması Çalıştayı, ODTÜ, Ankara, 6,1, (2005)

7. T.C. M E B, İnşaat Teknolojisi Deprem İzolatör Sistemleri 440FB000, 5-28, (2011)

8. S. Oymael, To provide the earthquake resistance in the structures and the sustainability of neighborhood relations, $X$. INTERNATIONAL SINAN SYMPOSIUM, 319-326, (2017)

9. V. Koç, 'Depreme Maruz Kalmış Yı̆̆ma ve Kırsal Yapı Davranışlarının İncelenerek Yı̆̆ma Yapı Yapımında Dikkat Edilmesi Gereken Kuralların Derlenmesi', Çanakkale Onsekiz Mart Üniversitesi Fen Bilimleri Enstitüsü Dergisi, 1-57, (2016)

10. J. Bothara, S. Brzev, A Tutorial: Improving the Seismic Performance of Stone Masonry Buildings, WHE-2011-01, Oakland, California, 12, 35-36, (2011) http://www.world-housing.net/wpcontent/uploads/2011/06/Stone_Masonry_English.pdf 
11. T. Schacher, Confined Masonry For one and two story buildings in low-tech environments, A guidebook for technicians and artisans, nicee National Information Centre of Earthquake Engineering, 13, (2009) https://www.pseau.org/outils/ouvrages/nicee_confined_masonry_1_2_storey_buil dings_schacher.pdf Access: 22.10.2017

12. http://sivrihisar.web.tr/sivrihisar-zaimaga-konagi.html, Access: 10.11. (2016)

13. A. Budak, H. Uysal, A. C. Aydın, Kırsal Yapıların Deprem Karşısındaki Davranış1, Atatürk Ziraat Fak. J. 35 (3-4), 209-219, (2004)

14. R. Langenbach. "Intuition from the Past: What we can learn from Traditional Construction", KEYNOTE ADDRESS AT THE ISTANBUL CONFERENCE, (2000) http://www.conservationtech.com/IstanCon/keynote.htm. Access: 22.10.2017 